\title{
Unwanted Effects of European Union Environmental Policy at Promoting a Post-carbon Industry. The Case of Energy in the European Ceramic Tile Sector
}

\author{
D. Gabaldón-Estevan ${ }^{1}$, A. Mezquita ${ }^{2}$, S. Ferrer ${ }^{2}$, E. Monfort ${ }^{2}$ \\ 1 Department of Sociology and Social Anthropology, University of Valencia. Spain \\ 2 Instituto de Tecnología Cerámica (ITC). Asociación de Investigación de las Industrias Cerámicas \\ (AICE), Universitat Jaume I. Castellón. Spain. \\ (E-mail: Daniel.Gabaldon@uv.es, ana.mezquita@itc.uji.es, salvador.ferrer@itc.uji.es, \\ eliseo.monfort@itc.uji.es)
}

\begin{abstract}
The context of global warming, and low carbon transition plans, are threatening the future of high energy consuming industrial sectors in the European Union (EU). The need to respond to environmental challenges is demonstrated by support for international level energy policies and legal requirements, such as the Kyoto Protocol which the EU supports, and increased EU-level environmental legislation and energy policies. The effect of these initiatives is gradually transforming industrial activity in the EU. However, since not all the countries involved have adopted these policies, their net effect needs to be assessed taking account of their side-effects, such as delocalization of industrial activity, and the different legal environmental frameworks in the countries where companies have chosen to relocate. This paper analyses EU energy policy and its real impact on a particular energy intensive industry, the European ceramic tile sector. ${ }^{1}$ The discussion in this paper is not about the purpose of EU legislation, but about its effects on a specific industry. The effect of policy on industry is not a new topic, but the question of the unwanted effects of environmental and energy policy on European industry is becoming more relevant as the struggle to achieve a post-carbon Europe increases. In focusing on a specific set of EU legislation on a particular industry we add to the debate by showing the negative effects of policy mechanisms. We highlight the need for a scientific evaluation of the systemic changes required for a transition to a resource-efficient, green and competitive low-carbon economy outlined in the 7th Environment Action Programme. We suggest the EU should periodically re-evaluate its Emission Trading Scheme legislation to include specific actions and a follow up system which would prevent the best performing environmental companies from delocalizing or shutting down.
\end{abstract}

Keywords: environmental policy, post carbon transition, EU policy, tile industry

\footnotetext{
${ }^{1}$ ACKNOWLEDGMENTS

This work was supported by the project ESTIBMEIC- GV/2014/049 (Generalitat Valenciana).
} 


\section{Introduction}

There is a growing concern about the unsustainability of the production model in the so-called developed countries, given the diminishing capacity of the environment to assimilate the impacts of economic activity in a non-traumatic way (Hajer, 1995; Huisingh et al., 2015; Lockie et al., 2013; Rockstrom et al., 2009). The situation is being exacerbated by the rapid growth of other economies especially Brazil, Russia, India and China (BRIC countries) and the consequent increase in demand for energy and raw materials to feed that growth (Pao and Tsai, 2010, 2011a,b). At the same time, there is increased public awareness of the diminishing capacity of the environment to assimilate the impacts of human activity, and increased demands for environmental sustainability (European Commission, 2014; Rogers et al., 2008). At the institutional level, this concern is reflected in support for energy policies and international legal requirements such as the Kyoto Protocol (Böhringer et al., 2009a,b; Huber, 2004; Jordan and Lenschow, 2000; Kivimaa and Mickwitz, 2011; López-Gamero et al., 2010; ; Vera and Langlois, 2007; Weber and Rohracher, 2012;). The debate over the sustainability of 'traditional' industries in the EU, such as the ceramic tile industry (Gabaldón-Estevan et al., 2014), is being fuelled by the major transformations resulting from the process of globalization and the economic crisis. We contribute to this debate by analysing EU environmental and energy policy and its impact on the EU ceramic tile sector.

Global warming and low carbon transition (COM (2011) 112 final, Directive 2012/27/EU) are posing huge challenges for high energy consuming manufacturing industry subsectors in the EU, especially those with relatively low productivity (Koroneos and Dompros, 2007) which are competing in the international market (such as the ceramic tile industry). The EU's commitment to lead responses to these environmental challenges, has resulted in a high level of legislative activity related to environmental (Directive 2010/75/EU, Directive 2011/91/EU) and, especially energy policy (Directive 2004/8/EC, COM (2011) 109 final). The effect of those initiatives is gradually transforming industrial activity within the EU. The new scenario, characterized by increasing pressure from environmental regulation $\left(\mathrm{CO}_{2}-\right.$ emission trading scheme (Directive 2009/29/EC, COMMISSION DECISION of 24 December 2009), use of BAT, etc.), favours non-EU competitors whose production often does not meet EU environmental standards, which benefit from lower energy prices and which, in some cases, have better access to raw 
materials. It is encouraging the relocation of production to places with conditions that are less favourable to the environment and to social and labour conditions.

Since the studies by Rubik and Scholl (2002) and Helby (2002), European environmental legislation has grown in complexity and scope (Oikonomou and Jepma, 2008). However, recent research on the effect of EU policy on environmental protection is not conclusive. Afionis and Stringer's (2012) work on biofuel regulation, shows that EU regulations prioritize competitiveness and economic growth over environmental protection while Gouldson et al. (2015) and Boeters and Koornneef (2011) suggest that the impact of EU environmental regulation sometimes is overestimated. Jänicke (2012) highlights the relevance of the policy dimension for understanding how the fulfilment and interactions between the technical innovation system functions influence the acceleration or deceleration of the "virtuous" or "vicious cycles" of the diffusion process. Westner and Madlener (2012) show that the EU's Emissions Trading Scheme (ETS) affects the attraction of investment for large-scale, combined heat and power plants. Maes et al. (2015) claim that the EU Renewable Energy Directive's sustainability guidelines need further development while de Miranda and Kruglianskas (2015) stress the need for reflexivity of environmental regulations.

EU environmental policy, apart from giving priority to energy efficiency in all energy domains, is aimed at a $20 \%$ reduction in greenhouse gas emissions by 2020 (from 1990 values) and a reduction in renewable energy sources deployment (to $20 \%$ of gross final energy consumption in 2020). The costs of compliance with this policy is estimated to be in around $0.4 \%$ to $0.6 \%$ of EU gross domestic product (GDP) in 2020 (Capros et al., 2011). However, implementing the changes required to meet the EU Directives targeting specific sustainable energy development objectives can have contradictory impacts (Streimikiene and Šivickas, 2008)

There is evidence of 'carbon leakage', but also studies that minimize or ignore its occurrence (Barker et al. 2007). Some suggest 'the potential for the global leakage rate to exceed $100 \%$; i.e. a policy to reduce carbon emissions in the industrialized countries actually increases global carbon emissions' (Babiker, 2005). Chen's (2009) study of regional greenhouse gas policy in the USA suggests that leakage and spillovers could be a concern. Kallbekken et al. (2007) affirm that the clean development mechanism contained in the Kyoto protocol, could potentially reduce carbon leakage significantly while Kuik and Hofkes (2010) suggest that border adjustments to prevent free-riding and carbon leakage, 
might be more effective in reducing the rates carbon leakage in some industries (iron and steel) than others (minerals, cement).

Since the level of environmental and energy policies varies, we need to assess the net effect of these initiatives. This includes taking account of the side effects of delocalization of industrial activities and the different national environmental legal frameworks under which companies operate. This paper provides an analysis of EU energy policy and its impact on the European ceramic tile sector. It is organized as follows: Section 2 describes the theoretical framework; Section 3 discusses the main characteristics of the European ceramic tile manufacturing process along its value chain (3.1) and the recent evolution of its market share and production (3.2), presents the available data on energy consumption in the ceramic tile industry (3.3), summarizes the legislation most relevant to the ceramic tile industry (3.4) and analyses the impact of EU energy policy on the European ceramic tile sector (3.5). Section 4 concludes by summarizing the main contributions of this paper.

\section{Theoretical framework}

Our analysis adopts a systems perspective on the impact of supra-national (EU level) legislation on the performance of an EU industry sector. There are various approaches to the study of innovation systems in evolutionary economics, which use various units of analysis. For instance, national innovation systems (Freeman and Soete, 1987; Lundvall, 1992; Nelson, 1993), regional innovation systems, related to specific areas within large territories (Cooke, 1996; Cooke and Morgan, 1993), technological systems, which focus mainly on the networks of agents in the generation, diffusion, and utilization of technologies (Callon, 1992; Carlsson and Stankiewicz, 1995; Hughes, 1984; Jacobsson and Johnson, 2000), sectoral systems, which looks at innovations in industries across political borders (Breschi and Malerba, 1997; Malerba, 2002), and district systems, which combine innovation system and industrial district approaches (Gabaldón-Estevan et al., 2012) and emphasize the relevance of territory for both the industrial district form and other elements of the innovation system.

From a systems perspective, legal and institutional frameworks are central for defining firm strategies since they affect the productive, scientific and technological environments (Figure 1). Similarly, socio-technical regimes can be understood as historical routines and optimization processes, 
which are institutionalized, materialized and aligned in multiple dimensions such as industry structures, technology and infrastructure, knowledge base, users and markets, culture, and policy and political power (Geels, 2002; Smith and Raven, 2012). This last refers to policy targets and priorities, administrative rules, power relations, etc., which influence the direction of search since 'new regulations, and changes to markets or competitors, are all factors that affect the activities in sectors, in terms of the way they perform their activities, or the range of activities they perform' (Gabaldón-Estevan and Hekkert, 2013).

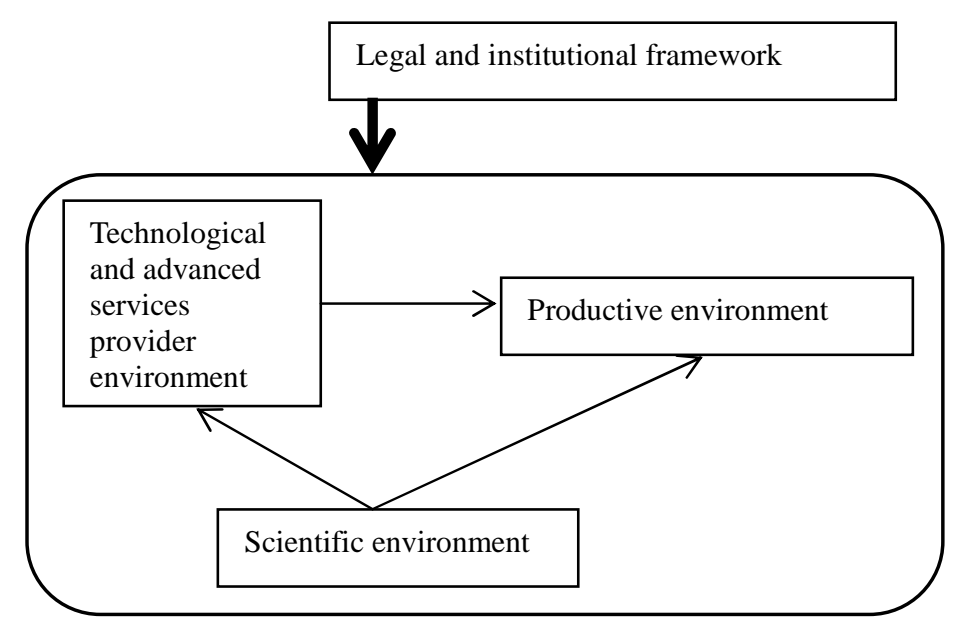

Figure 1 Schematic illustration of the main elements on an innovation system, adapted from (Fernández et al., 1996)

The analysis involves three steps: (1) describing the main characteristics of the European ceramic tile manufacturing process along its value chain with specific emphasis on the energy intensity of each stage; (2) analysing thermal and electrical energy consumption in the ceramic tile industry; and (3) evaluating the impact of EU energy policy on the European ceramic tile sector.

We exploit secondary data collected from various sources including specialist sectoral publications and statistics. We use data on EU level environmental policy to map the policy measures that influence the development of the ceramic tile industry, drawn from EUR-Lex, the EU legislation database. 


\section{Analysing the evidence}

This section has five sub-sections. Section 3.1 discusses the main characteristics of the European ceramic tile manufacturing process along its value chain and Section 3.2 presents the European ceramic tile industry market share and production to provide the background to this sector. Section 3.3 presents the available data on energy consumption in the ceramic tile sector in order to specify the industry's energy consumption characteristics. Section 3.4 summarizes the legislation most relevant to the ceramic tile industry regarding its impacts on the industry. Section 3.5 analyses the impact of EU energy policy on the European ceramic tile sector.

\subsection{THE EUROPEAN CERAMIC TILE MANUFACTURING PROCESS}

The stages in the ceramic tile manufacturing process vary according to the function of the manufactured product. The main ceramic tile production stages are:

(1) Raw materials preparation. Appropriate raw materials are selected and proportioned to achieve the desired product characteristics. Their quality (i.e. impurities content) determines their suitability for tile production and the product's final cost, which, to an extent, is dependent on the distance between mine and plant. Use of local raw materials is maximized to reduce manufacturing costs, but some raw materials have to be imported from other regions or countries, including non-EU countries (e.g., white clays imported mostly from Ukraine, and feldspars imported from Turkey). In the pressing stage, the raw materials mix is subjected to wet or dry milling. Wet milling is the most frequent preparation method in Europe, owing to the properties of the granules obtained by spraying; however, from an energy point of view, dry milling is more efficient. Wet milling accounts for $30 \%$ of the thermal energy consumed in ceramic tile production;

(2) Ceramic tile forming. Ceramic tile bodies are generally formed by pressing, using hydraulic presses which consume electric energy;

(3) Drying. The formed tile bodies are subjected to a drying cycle to reduce the moisture content, which varies according to the type of forming process. This stage accounts for around $10 \%$ of total thermal energy consumed; 
(4) Glazing and decorating. After drying, the ceramic tiles are usually glazed and decorated. The process consists of the application of various glaze layers depending on the mechanical or aesthetic properties desired, followed by decoration which is done by digital inkjet;

(5) Firing. In this final production stage, the ceramic tiles are subjected to a thermal cycle where temperatures range from $1100^{\circ} \mathrm{C}$ to $1200^{\circ} \mathrm{C}$, depending on the product. This stage accounts for more than $50 \%$ of total thermal energy consumption in the manufacturing process.

A single firing process means the tile body and glaze are fired simultaneously. Double firing refers to when the tile body is fired before being decorated and then is fired for a second time fix the glaze. The most common ceramic tile manufacturing process in Europe is single-firing (see Figure 2).

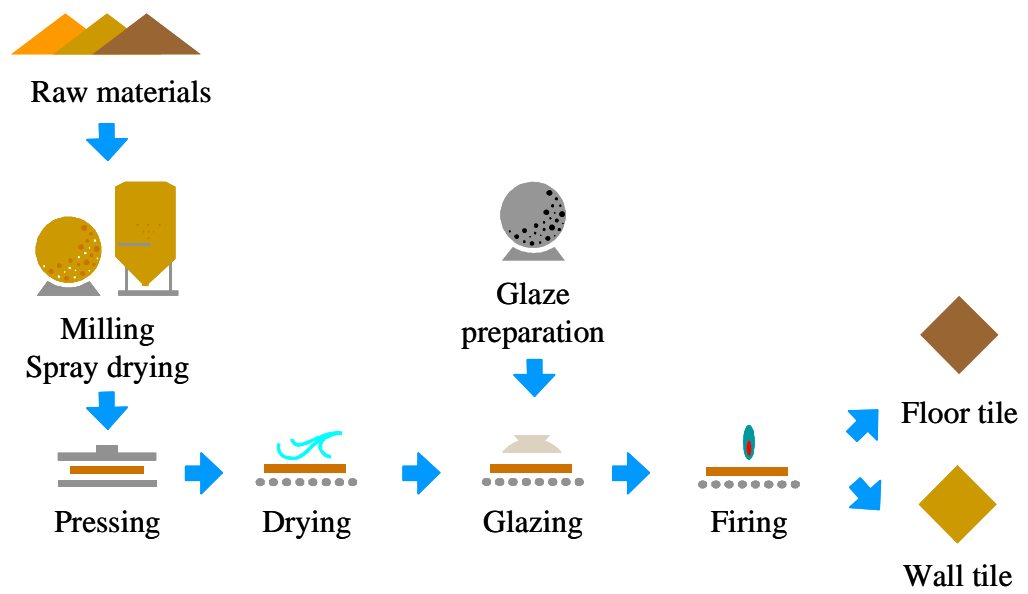

Figure 2 Schematic illustration of the single-fired ceramic tile manufacturing process, own elaboration.

\subsection{THE EUROPEAN CERAMIC TILE INDUSTRY - MARKET SHARE AND PRODUCTION}

Wall and floor ceramic tiles constitute the biggest sector (measured by turnover) in European ceramic industries, with total sales in 2013 estimated at around $€ 9$ billion. A third of ceramic tile production is exported outside of the EU, resulting in a largely positive trade balance, with exports representing four times EU imports of ceramic tiles in value. ${ }^{2}$

The European ceramic tile industry has been the world leader for design and innovation and continues to set the trend for new designs and functionalities. Ceramic tiles cover a wide range of product

${ }^{2}$ www.cerameunie.eu 
categories which satisfy technical and aesthetic needs related to both traditional and modern indoor and outdoor environments. Ceramic tiles have many functional characteristics including increasing hygiene and safety. Their resistance to light exposure and chemical attacks, and their ease of maintenance makes ceramic tiles important for the sustainability of buildings.

European ceramic tile production has increased continuously from 1980 to 2006, reaching a maximum annual production of around 1,500 million $\mathrm{m}^{2}$. The global financial crisis caused this value to decrease in 2009 to 1,079 million $\mathrm{m}^{2}$ (Giacomini, 2010). However, since then, European ceramic tile production has slowly increased to reach 1.186 million $\mathrm{m}^{2}$ in 2013 , due mainly to increased exports (Stock, 2014).

At the same time, world ceramic tile production has increased continuously since 2006 and, after 2008, the European ceramic tile industry lost relative weight in the world ceramic tile industry. For example, the percentage of European tile manufacturing in world production decreased from $16.6 \%$ in 2008 to $10 \%$ in 2013. Figure 3 shows the evolution of European and world ceramic tile production, and the percentage production in Europe since 2008.

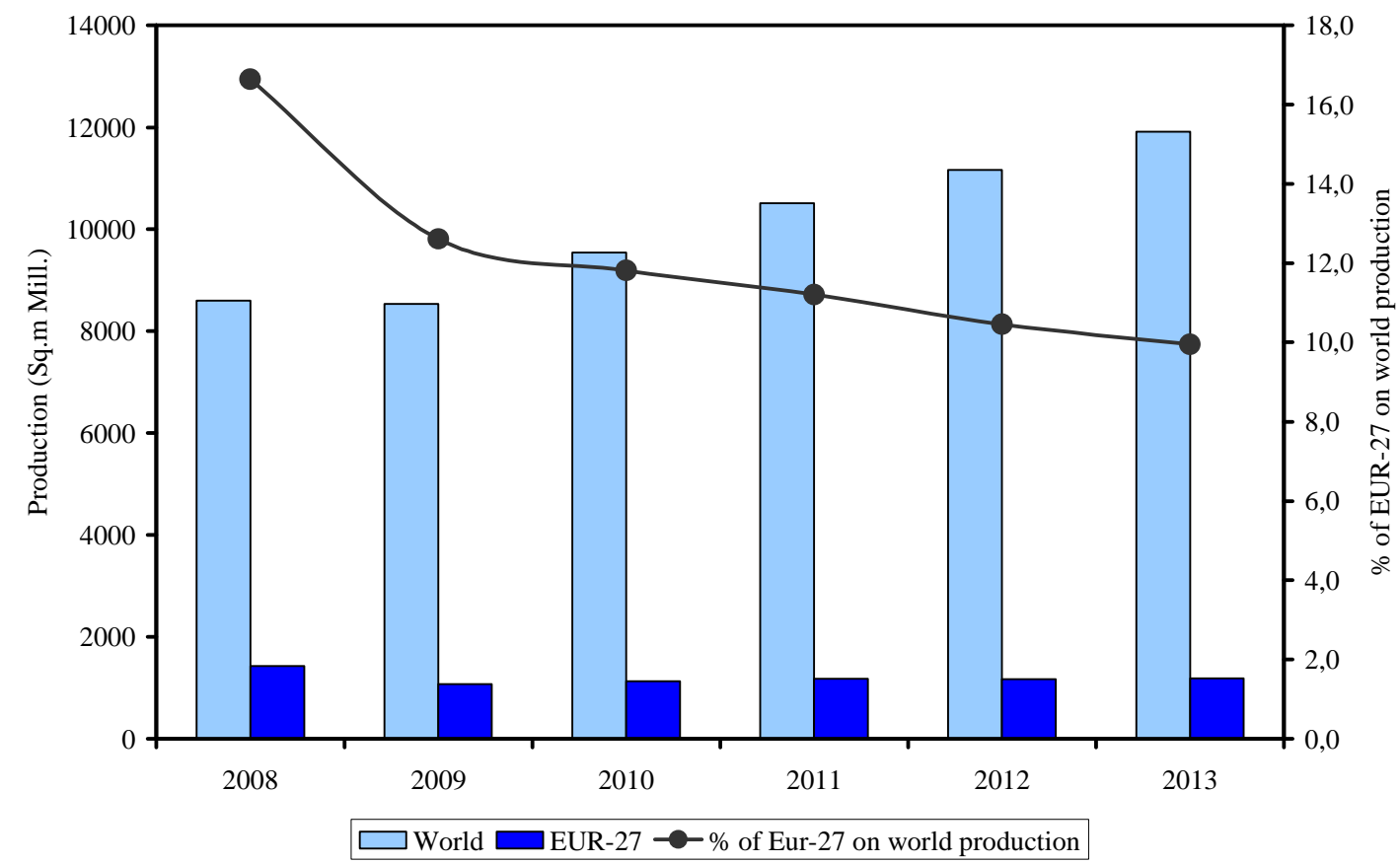

Figure 3 Tile production in EU-27 and in the world 2008-2013 (own elaboration from Giacomini 2010; and Stock, 2014) 
Italy and Spain are the biggest ceramic tile producers in the EU, accounting for some $66 \%$ of production; however, Poland, Portugal, Germany, France, Bulgaria, the UK, Romania, the Netherlands, Czech Republic, and Hungary are also significant producers. Figure 4 shows the evolution of Spanish and Italian ceramic tile production from 1981.

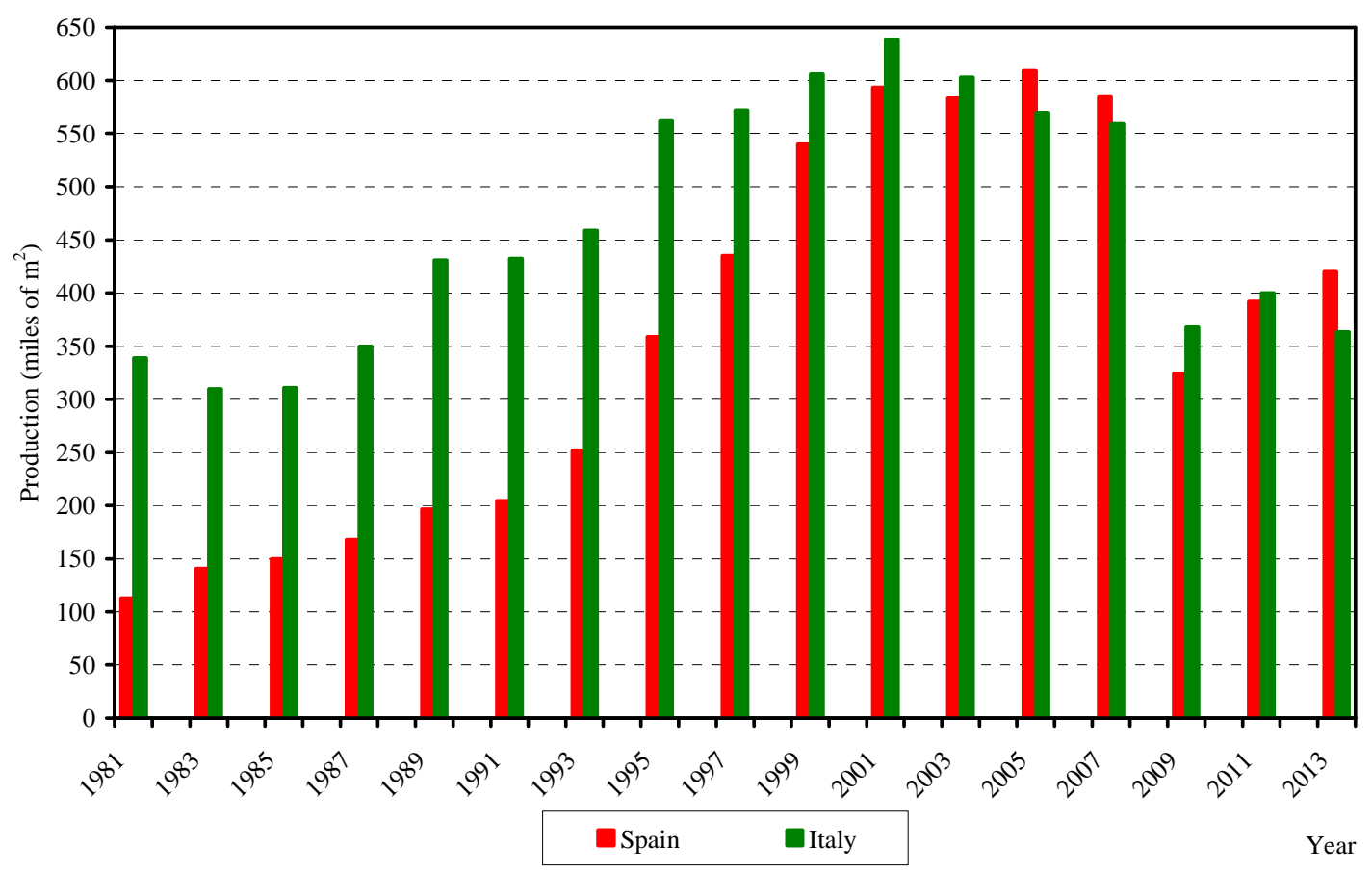

Figure 4 Evolution of ceramic tile production in Spain and Italy 1981-2013 (Cofindustria Ceramica, 2010;

Stock, D.P., 2014)

\subsection{ENERGY USE AND CONSUMPTION IN THE EUROPEAN CERAMIC TILE INDUSTRY}

The ceramic tile industry consumes considerable amounts of energy along its value chain. The main energy consuming phases are mining, transport of raw materials to the processing plants, the manufacturing process, and storage and delivery of the ceramic tiles once packaged. The energy involved in the use and end of life phases can be considered negligible (Benveniste et al., 2010). Transport of raw materials to the plants and the product to markets - the two ends of the production chain - are by truck (small and medium distances) and ship (longer distances). The manufacturing process is an intensive thermal energy consumer (around $28 \mathrm{kwh} / \mathrm{m}^{2}$ ) (Monfort et al., 2010). Since the 1980s, European ceramic tile plants have been fuelled mainly by natural gas. In some countries, such as Spain, the majority 
of spray-dried powder producers have installed cogeneration units (producing heat and electric energy simultaneously), which has increased their total energy efficiency to between $85 \%$ and $90 \%$ in this stage. The use of cogeneration systems in ceramic tile companies in the EU is linked strongly to national energy policies, which explains the significant differences among EU countries in the degree of implementation of this highly efficient technology.

In the ceramic tile industries that rely on cogeneration units, part of the electricity produced is used in the manufacturing process, and the thermal energy from the combustion gases in the cogeneration unit is recovered for use in the spray dryer. This increases the energy efficiency, due to the reduced primary energy consumption. In plants with no cogeneration system the heat needed for the manufacturing process is produced by fossil fuel combustion or electricity is supplied by the general grid. However, it should be noted that conventional thermal power stations are typically less energy efficient overall (about 35\%-55\%, depending on the technology used) because the combustion gases are released into the atmosphere with no energy recovery.

Electric energy is also needed for transportation (conveyor belts, robots, etc.), presses, fans, etc. In the case of cogeneration systems, the net electricity balance is positive. According to some studies (Monfort et al., 2010, 2014; Nassetti et al., 1998; Timellini and Blasco Fuentes, 1993), the majority of European ceramic tile companies are using the Best Available Techniques (BAT) in terms of energy efficiency; thus, although there are some additional saving measures that can be implemented, in the absence of any breakthrough developments, further significant reductions in energy consumption are not envisaged (Gabaldón-Estevan et al., 2014). The trend in energy costs and increasing concern in the EU over carbon dioxide $\left(\mathrm{CO}_{2}\right)$ emissions may become major hurdles for European ceramic tile companies in the short term. 


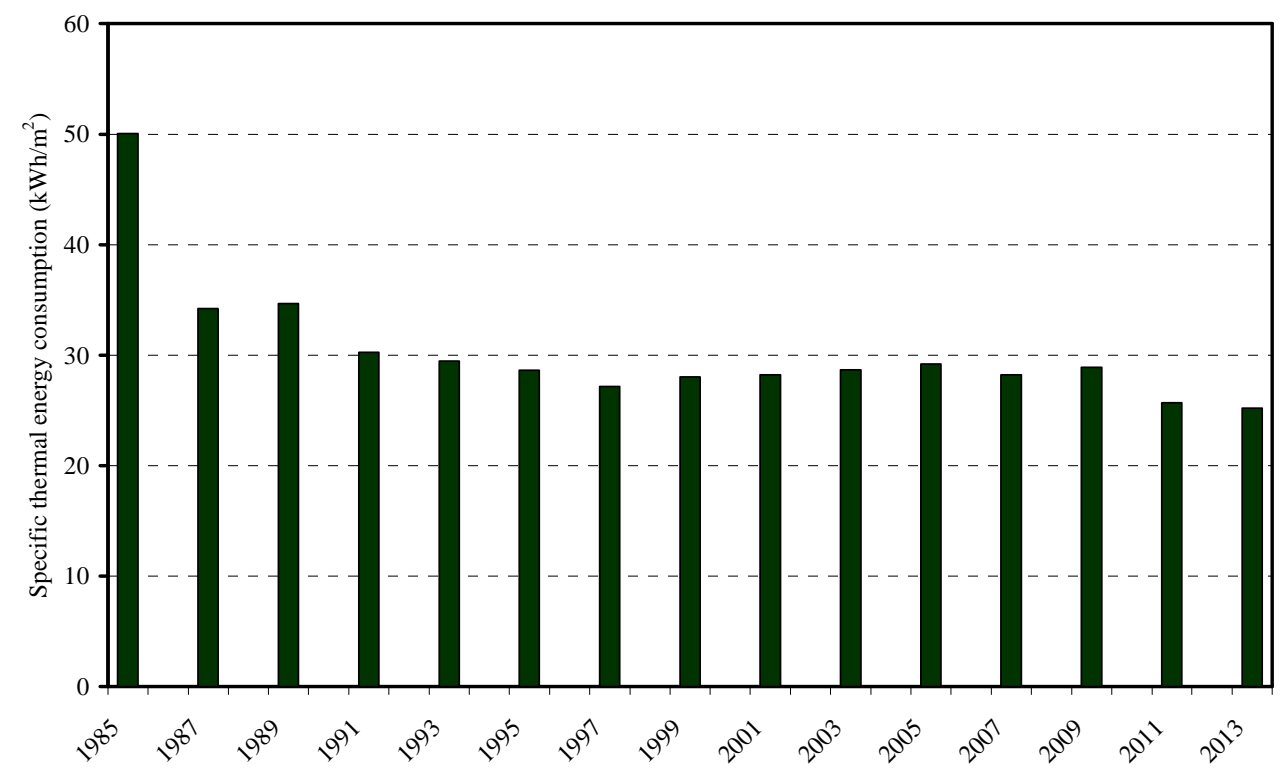

Figure 5 Evolution of specific thermal energy consumption in the ceramic tile manufacturing process in

Spain (Monfort et al., 2014)

Figure 5 shows the evolution of thermal energy consumption in Spanish manufacturing since 1985. Between 1985 and 1990 companies dramatically reduced their consumption of thermal energy through the adoption of new technologies (single firing, roller kilns, cogeneration systems, etc.) and natural gas instead of heavy oil or gasoil. Since this innovative period, consumption of thermal energy has remained fairly stable with no major changes to energy efficiency. The slight reduction observed after 2010 may be explained by some minor improvements related to energy recovery systems and implementation of larger kilns. Although the values shown are for Spain, they can be considered representative of the European ceramic tile industry, and very similar to Italian data (Nassetti et al., 1998; Timellini and Blasco Fuentes, 1993).

$\mathrm{CO}_{2}$ emissions have followed a similar trend (Figure 6) since most $\mathrm{CO}_{2}$ emissions are from the combustion process (90\%). The remaining $10 \%$ corresponds to the decomposition of the carbonates used for the body composition of earthenware (wall) tiles; hence the floor/wall tile production ratio has a minor effect on total $\mathrm{CO}_{2}$ emissions. 


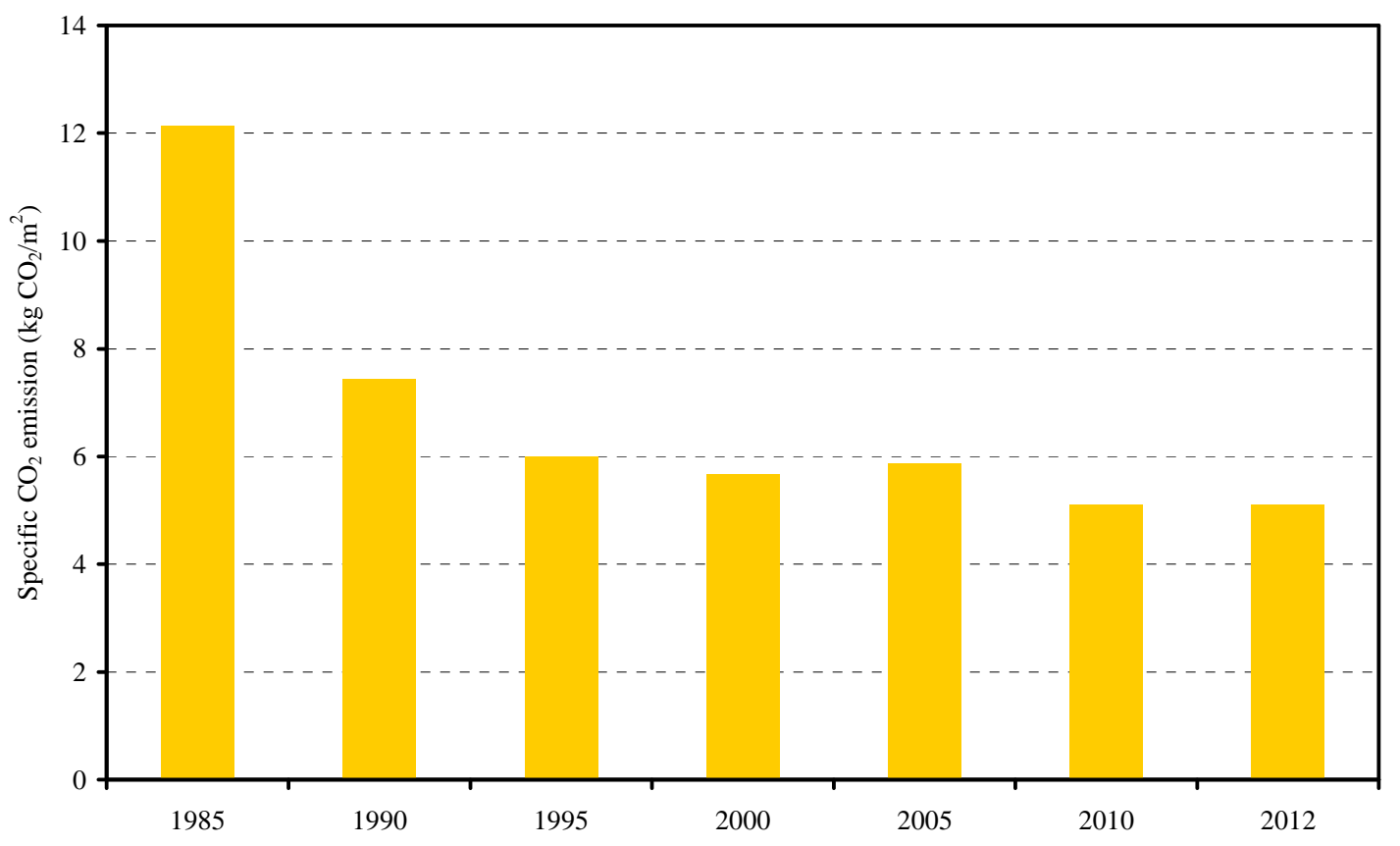

Figure 6 Evolution of the specific $\mathrm{CO}_{2}$ emission in Spain (Monfort et al., 2014)

Regarding electric energy consumption in the manufacturing process, the most recent studies indicate average values of around $3.2 \mathrm{kwh} / \mathrm{m}^{2}$ (Monfort et al., 2010), much lower than consumption of thermal energy $\left(26 \mathrm{kwh} / \mathrm{m}^{2}\right)$. Electric energy is involved in the materials handling (conveyor belts, robots, etc.) and forming (hydraulic presses) stages, the water and gas cleaning systems (pumps, fans, etc.), driers and kilns (fans, control units), etc. Nevertheless, in Spain, where cogeneration systems have been implemented in the last 20 years, the net electricity balance at cluster level is positive (Monfort et al., 2010).

\subsection{EU ENVIRONMENTAL AND ENERGY POLICY}

This section summarizes the legislation most relevant to the ceramic tile industry. In the following, we list its impacts on the ceramic tile industry:

- Directive 2004/8/EC Of The European Parliament and of the Council of 11 February 2004 on the promotion of cogeneration based on a useful heat demand in the internal energy market;

- Directive 2009/29/EC of the European Parliament and of the Council of 23 April 2009 
amending Directive 2003/87/EC so as to improve and extend the greenhouse gas emission allowance trading scheme of the Community;

- Directive 2010/75/EU of the European Parliament and of the Council of 24 November 2010 on industrial emissions (integrated pollution prevention and control);

- $\operatorname{COM}(2011) 109$ final Communication from the Commission to the European Parliament, the Council, the Economic and Social Committee and the Committee of the Regions of 8 March 2011 - Energy Efficiency Plan 2011;

- COM (2011) 112 final. Communication from the Commission to the European Parliament, the Council, the European Economic and Social Committee and the Committee of the Regions. A Roadmap for moving to a competitive low carbon economy in 2050;

- Directive 2012/27/EU of the European Parliament and of the Council of 25 October 2012 on energy efficiency;

- COMMISSION DECISION of 24 December 2009 determining, pursuant to Directive 2003/87/EC of the European Parliament and of the Council, a list of sectors and subsectors which are deemed to be exposed to a significant risk of carbon leakage;

- $\operatorname{COM}(2014) 21$ final. Communication from the commission to the European parliament, the council, the European economic and social committee and the committee of the regions. Energy prices and costs in Europe.

Among these documents, we would highlight the EU's roadmap, published by the European Commission in 2011, to achieve a low-carbon economy (COM (2011) 112 final). This document specifies the emissions reduction targets set by the EU for industrial sectors, establishing a reduction in $\mathrm{CO}_{2}$ emissions of between $83 \%$ and $87 \%$ by 2050 .

\subsection{THE IMPACT OF EU ENERGY POLICY ON THE EUROPEAN CERAMIC TILE SECTOR}

For more than 30 years, the European ceramic tile industry has been working to reduce energy consumption and $\mathrm{CO}_{2}$ emissions through the adoption of innovative technologies and the implementation of energy saving actions. However, meeting the $2050 \mathrm{EU}$ targets will require another technology revolution and implementation of breakthrough technologies. 
The most recent European policy, such as the ETS, is challenging European energy intensive industries. Although the ETS is considered positive for promoting research, investment and activities (energy audits, energy consumptions control, implementation of energy saving actions, etc.) focused on reducing $\mathrm{CO}_{2}$ emissions, there are some aspects of it that should be refined to avoid unaffordable costs and consequent relocation of ceramics factories in areas with less stringent environmental regulation.

Almost all European ceramic tile manufacturers are affected by the ETS (Directive 2009/29/EC). To counter the risks of relocation of manufacturing industries outside the EU for reasons of cost and climate policies, and loss of employment in Europe, the European Commission has established criteria to determine whether a manufacturing industrial sector is at risk of carbon leakage, based on the economic impact of the application of the ETS on production costs and the sector's trade intensity (imports and exports) with countries outside the EU.

The European ceramic tile industry is one of the sectors at risk of carbon leakage (Commission Decision of 24 December 2009), and so receives some free emissions allowances. In the new EU ETS (since 2013) the allocation of free allowances is based on the most efficient industries, rather than on historical data (former EU ETS). There is a maximum number of free allowances for each industry sector which must be shared among all the relevant companies, with the result that the best performers may not receive all the free allowances requested (Ceramic Industry Manifesto 2014-2019).

The list of countries exposed to a carbon leakage will be revised every five years. The number of free allowances is reduced annually, so the situation for ceramics companies is becoming increasingly difficult and the threat of competition from outside the EU is growing due to the direct (allowances to buy) and indirect (management system and audits) costs of ETS implementation.

Figure 7 shows the prices of EU Allowances (EUA) from the beginning of the new ETS period (2013-2020) and shows that the value has been growing since April 2013, from $€ 3 / \mathrm{t}$ to more than $€ 8 / \mathrm{t}$ in 2015 . 


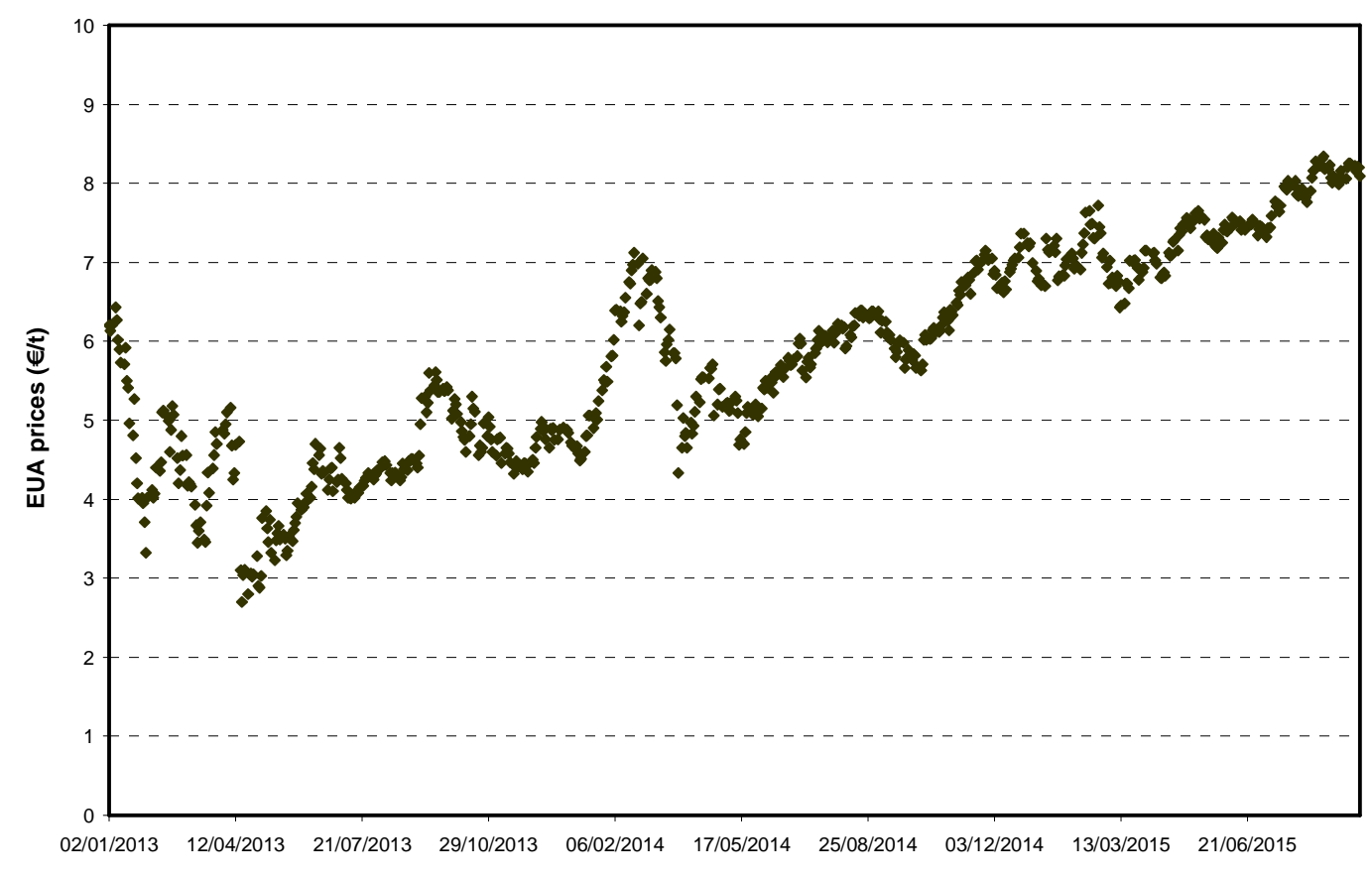

Figure 7 Evolution of the EUA prices ${ }^{3}$

In this new scenario, European companies are being forced to reduce their $\mathrm{CO}_{2}$ emissions in the medium and long-term. The EU 2011 roadmap offers guidance for moving to a low-carbon economy in 2050. This document provides objectives related to reducing $\mathrm{CO}_{2}$ emissions in all industry sectors including ceramics with the aim of achieving the $83 \%$ to $87 \%$ reductions by 2050 . The European Ceramic Industry's response in 2012 was to publish its Roadmap to 2050 (Cerame-Unie, 2012). This suggests that in the short-term, BAT should be adopted by all manufacturing countries although they will not be sufficient to achieve the ambitious European objectives, which will require the development of breakthrough technologies and new energy sources.

Based on life cycle assessment study estimates (Monfort et al., 2013, 2014), to achieve a more than $50 \%$ reduction in $\mathrm{CO}_{2}$ emissions in the manufacturing process will require low-carbon and cheaper electricity production systems to allow the use of electric driers and kilns (resistances, microwaves, plasma, etc.) with minimum $\mathrm{CO}_{2}$ emissions. Alternative fuels, such as biomass or biogas, would decrease emissions, but less significantly. In addition to $\mathrm{CO}_{2}$ emissions reduction costs linked to EU policies, energy prices need to be considered. Energy costs are estimated to be two to four times higher in

\footnotetext{
${ }^{3}$ http://www.sendeco2.com/, retrieved 18 September, 2015.
} 
Europe than in competing countries. Since energy costs represents around 30\% of manufacturing costs in the ceramic tile sector, policies affecting energy costs are a crucial factor in the survival of the European industry (Ceramic Industry Manifesto 2014-2019).

Table 1 presents average natural gas and electricity prices related to the European ceramic tile industry; in 2010 to 2012, they increased by $27 \%$ for natural gas, and $21 \%$ for electricity.

Table 1 Average energy prices for the European ceramic tile industry (COM (2014) 21 Final)

\begin{tabular}{|c|c|c|c|c|}
\hline Energy source & $\mathbf{2 0 1 0}$ & $\mathbf{2 0 1 1}$ & $\mathbf{2 0 1 2}$ & \% change 2010-2012 \\
\hline Natural gas price $(€ / \mathrm{MWh})$ & 25.0 & 26.2 & 31.7 & 26.8 \\
\hline Electricity price $((€ / \mathrm{MWh}))$ & 80.8 & 88.8 & 97.6 & 20.8 \\
\hline
\end{tabular}

Breakthrough innovations and renewable sources of energy are linked to institutional and financial support for research. Therefore, EU research policies play a central role in the future of energy-intensive industries. Since the mid-1980s, European companies have been world innovators in the ceramic sector in relation to machinery and materials. However, it is becoming more difficult to benefit from European and domestic research programmes because they tend to favour research in advanced materials and leading sectors (biomedicine, pharmacy, etc.), and there is a shortage of funding for the traditional sectors (Gabaldón-Estevan et al., 2014; Tello and Weerdmeester, 2013).

\section{Conclusions}

The European ceramic tile industry has adopted innovative technologies and implemented energy saving actions to reduce its energy consumption and $\mathrm{CO}_{2}$ emissions, and is using the BAT. However, new regulation and environmental policies are requiring more innovation and are resulting in the relocation of ceramics factories outside the EU, in areas with less strict environmental policies.

The new ETS Directive has had an impact on almost all European ceramic tile manufacturers. Its overall effect should be to promote research, investment and other activities directed to reducing $\mathrm{CO}_{2}$ emissions. However, it does not provide a fair, mid-term solution for companies that have continuously updated their industrial facilities. The free allowances received by the sector, which is exposed to the risk of carbon leakage, are based on the most efficient industries rather than on historical data. Also, the number of allowances is not sufficient for all the companies in the sector and even the best energy per- 
formers may not receive all they request. The scheme is revised every five years, and the number of free allowances is reduced annually, so the situation for ceramics companies will worsen, as will their competitiveness with manufacturers outside the EU due to the direct costs (buying allowances) and the indirect costs (management system and audits) of implementing the ETS.

To survive this new scenario, which includes reducing $\mathrm{CO}_{2}$ emissions by between $83 \%$ and $87 \%$ by 2050, European companies must begin reducing their $\mathrm{CO}_{2}$ emissions in the medium term. However, this will need another technological revolution. For instance, to reduce $\mathrm{CO}_{2}$ emissions by more than $50 \%$, will require decarbonization and cheaper electricity production in Europe to allow the use of electric driers and kilns with minimum $\mathrm{CO}_{2}$ emissions. Use of biomass or biogas as fuels will not produce sufficient emissions reductions to meet the 2050 target.

Another pressure on the competitiveness of energy-intensive industries is the price of energy which is affected indirectly by EU policies. Energy costs, which represent around a third of ceramic tile manufacturing costs, are two to four times higher in the EU than in competing countries; therefore, policies affecting energy costs will be crucial for the survival of the European industry.

Finally, as the systems perspective predicts, the implementation of breakthrough technologies, including the use of renewable sources of energy, is linked to institutional and financial support for research activities. EU research policies will play a central role in the future of energy-intensive industries. Many European and domestic research programmes are focused on advanced materials and new sectors (biomedicine, pharmacy, etc.), resulting in an increasing shortage of funds to support the so-called traditional sectors. Only a more comprehensive research financing scheme that includes research support for these traditional sectors - described by Jacobsson et al. (2009) as the innovation/industrialization challenge - will help ceramic tile and other European industry sectors to continue to lead the transition to a low-carbon economy.

To summarize, the question of the unwanted effects of environmental and energy policy on European industry is becoming especially important in the struggle to achieve a post-carbon Europe. We focused on a specific set of EU legislation related to one particular industry and showed how policy mechanisms operate to produce negative effects. This paper highlights the need for a scientific evaluation of the systemic changes required for a transition to a resource-efficient, green and competitive lowcarbon economy described in the 7th Environment Action Programme. By studying the effect of EU 
policy on the ceramic tile industry we have revealed the challenges faced by this industry regarding energy consumption and $\mathrm{CO}_{2}$ emissions. Replication of our study for other industries would provide a clearer picture and contribute to assessments of public-sector interventions. Overall, we conclude that the EU should periodically re-evaluate its legislation concerning the ETS Directive in order to refine/include specific actions, and implement a follow up system to prevent the unwanted effects of environmental and energy policy, such as relocation or shutting down of the companies with the best environmental performance.

\section{References}

Afionis, S., Stringer, L. C., 2012. European Union leadership in biofuels regulation: Europe as a normative power?. J Clean Prod, 32, 114-123.

Babiker, M. H. 2005. Climate change policy, market structure, and carbon leakage. J . Int. Econ. 65(2), 421-445.

Barker, T., Junankar, S., Pollitt, H., Summerton, P., 2007. Carbon leakage from unilateral environmental tax reforms in Europe, 1995-2005. Energ Policy, 35(12), 6281-6292.

Benveniste, G., Gazulla, C., Fullana, P., Celades, I., Ros, T., Moliner, R., Zaera, V., Godes, B. 2010. Sectoral Life Cycle Analysis Of Ceramic Tile. In: Qualicer 2010: XI World Congress on ceramic tile quality. Castellón: Cámara Oficial de Comercio, Industria y Navegación.

Boeters, S., Koornneef, J., 2011. Supply of renewable energy sources and the cost of EU climate policy. Energ Econ, 33(5), 1024-1034.

Böhringer, C., Löschel, A., Moslener, U., Rutherford, T. F., 2009a. EU climate policy up to 2020: An economic impact assessment. Energ Econ, 31, S295-S305.

Böhringer, C., Rutherford, T. F., Tol, R. S. 2009b. The EU 20/20/2020 targets: An overview of the EMF22 assessment. Energ Econ, 31, S268-S273.

Breschi, S., Malerba, F., 1997. Sectoral Systems of Innovation: technological regimes, Schumpeterian dynamics and spatial boundaries. In Edquist, C. (Ed.). Systems of Innovation. Frances Pinter, London.

Callon, M., 1992. The dynamics of techno-economic networks. In Coombs, R. y Walsh, V. (Eds.). Technical change and company strategies: Economic and sociological perspectives, Harcourt Brace Jovanovich Publishers, San Diego, 72-102

Capros, P., Mantzos, L., Parousos, L., Tasios, N., Klaassen, G., Van Ierland, T., 2011. Analysis of the EU policy package on climate change and renewables. Energ Policy, 39(3), 1476-1485.

Carlsson, B., Stankiewicz, R.,1995. On the Nature, Function and Composition of Technological Systems. In Carlsson, B. (ed.) Technological systems and economic performance: the case of factory automation, Boston, Dordrecht and Londres, Kluwer Academic Publishers.

Cerame-Unie 2012. Paving the way to 2050: the Ceramic Industry Roadmap. Available at: http://cerameunie.eu/en/doc/197/CU\%20Ceramic\%20Roadmap\%202p.pdf

Ceramic Industry Manifesto 2014-2019: Paving the way for growth and jobs in Europe. 2014. Cerame Unie. The European Ceramic Industry Association. Available at: http://www.cerameunie.eu/en/publications/brochures-and-reports

Chen, Y., 2009. Does a regional greenhouse gas policy make sense? A case study of carbon leakage and emissions spillover. Energ Econ, 31(5), 667-675.

Cofindustria Ceramica, 2010. Indagini statistiche sull'industria italiana.

COM (2011) 109 final Communication from the Commission to the European Parliament, the Council, the Economic and Social Committee and the Committee of the Regions of 8 March 2011 - Energy Efficiency Plan 2011. 
COM (2011) 112 final. Communication From The Commission To The European Parliament, The Council, The European Economic And Social Committee And The Committee Of The Regions. A Roadmap for moving to a competitive low carbon economy in 2050.

COM (2014) 21 Final. Communication from the commission to the European parliament, the council, the European economic and social committee and the committee of the regions. Energy prices and costs in Europe.

COMMISSION DECISION of 24 December 2009 determining, pursuant to Directive 2003/87/EC of the European Parliament and of the Council, a list of sectors and subsectors which are deemed to be exposed to a significant risk of carbon leakage

Cooke, P.,1996. Regional innovation system: concepts, analysis, and typology. At RESTPOR 96: global comparison of regional RTD and innovation strategies for development and cohesion. Working paper, European commission, Brussels.

Cooke, P., Morgan, K., 1993. The Network Paradigm: New Departures in Corporate and Regional Development. Environ Plann D. 11 (5): 543-564

de Miranda Ribeiro, F., Kruglianskas, I., 2015. Principles of environmental regulatory quality: a synthesis from literature review. J Clean Prod, 96, 58-76.

Directive 2004/8/EC of The European Parliament and of the Council of 11 February 2004 on the promotion of cogeneration based on a useful heat demand in the internal energy market.

Directive 2009/29/EC of the European Parliament and of the Council of 23 April 2009 amending Directive 2003/87/EC so as to improve and extend the greenhouse gas emission allowance trading scheme of the Community.

Directive 2010/75/EU of the European Parliament and of the Council of 24 November 2010 on industrial emissions (integrated pollution prevention and control).

Directive 2011/91/EU of the European Parliament and of the Council of 13 December 2011 on the assessment of the effects of certain public and private projects on the environment.

Directive 2012/27/EU of the European Parliament and of the Council of 25 October 2012 on energy efficiency.

European Commission. (2014). Special Eurobarometer 416: Attitudes of European citizens towards the environment. Accessed 2nd of 2015 . http://ec.europa.eu/public opinion/archives/ebs/ebs 416_en.pdf

Fernández, I., Conesa, F., Garea, M., Castro, E., Gutiérrez, A., Bodegas, M.A. (coor.). 1996. Estructuras de interfaz en el sistema español de innovación. Su papel en la difusión de tecnología. Valencia: Universidad de Politécnica de Valencia.

Freeman, C., Soete L. (eds.)., 1987. Technical Change and Full Employment, Oxford: Basil Blackwell.

Gabaldón-Estevan, D. Hekkert M. P. 2013 How Does the Innovation System in the Spanish Tile Sector Function? Bol Soc Esp Ceram V. 52 (3) 151-158

Gabaldón-Estevan, D., Criado, E., Monfort, E., 2014. The Green Factor in European Manufacturing: A case study of the Spanish ceramic tile industry. J Clean Prod.70, 242-250.

Gabaldón-Estevan, D., Fernández-de-Lucio, I., Molina-Morales, F.X. 2012. Sistemas Distrituales de Innovación. ARBOR.188 (753), 63-73

Geels, F. W., 2002.Technological transitions as evolutionary reconfigurations processes.Res Policy A multi-level perspective and a case study. Res Policy. 31, 1257-1274

Giacomini, P. 2010.World production and consumption of ceramic tiles. Ceramic World review. 88, 5268

Gouldson, A., Carpenter, A., Afionis, S., 2015. Environmental leadership? Comparing regulatory outcomes and industrial performance in the United States and the European Union. $J$ Clean Prod. 100, 278-285.

Hajer, M. A., 1995. The politics of environmental discourse: ecological modernization and the policy process. Oxford: Clarendon Press.

Helby, P. 2002. Environmental agreements at European Community level—reflections based on member state experience. J Clean Prod. 10(2), 183-193.

Huber, J. 2004. New technologies and environmental innovation. Edward Elgar Publishing.

Hughes, T., 1984 The evolution of large technological systems. In Bijker, W., Hughes, T., Pinch, T. (Eds.). The social construction of technological systems: New directions in the sociology and history of technology, MIT Press, Cambridge, MA.:51-82

Huisingh, D., Zhang, Z., Moore, J. C., Qiao, Q., Li, Q., 2015. Recent advances in carbon emissions reduction: policies, technologies, monitoring, assessment and modeling. J Clean Prod, 103, 1-12. 
Jacobsson, S., Bergek, A., Finon, D., Lauber, V., Mitchell, C., Toke, D., Verbruggen, A., 2009. EU renewable energy support policy: Faith or facts? Energ Policy. 37(6), 2143-2146.

Jacobsson, S., Johnson, A., 2000. The diffusion of renewable energy technology: an analytical framework and key issues for research. Energ Policy. 28(9), 625-640.

Jänicke, M., 2012. Dynamic governance of clean-energy markets: how technical innovation could accelerate climate policies. J Clean Prod. 22(1), 50-59.

Jordan, A., Lenschow, A., 2000. 'Greening' the European Union: what can be learned from the 'leaders' of EU environmental policy? Eur Environ. 10(3), 109-120.

Kallbekken, S., Flottorp, L. S., Rive, N., 2007. CDM baseline approaches and carbon leakage. Energ Policy. 35(8), 4154-4163.

Kivimaa, P., Mickwitz, P., 2011. Public policy as a part of transforming energy systems: framing bioenergy in Finnish Energ Policy, J Clean Prod, 19 (16) 1812-1821.

Koroneos, C., Dompros, A. 2007. Environmental assessment of brick production in Greece. Buil and Environ. 42(5), 2114-2123.

Kuik, O., Hofkes, M., 2010. Border adjustment for European emissions trading: Competitiveness and carbon leakage. Energ Policy. 38(4), 1741-1748.

Lockie, S., Sonnenfeld, D. A., Fisher, D. R. (Eds.)., 2013. Routledge international handbook of social and environmental change. Routledge.

López-Gamero, M. D., Molina-Azorín, J.F., Claver-Cortés, E., 2010. The potential of environmental regulation to change managerial perception, environmental management, competitiveness and financial performance. J Clean Prod. 18 (10-11) 963-974.

Lundvall, B. A. 1992. Introduction. In Lundvall, BA. (ed.) National Systems of Innovation: toward a Theory of Innovation and Interactive Learning. Pinter Publishers. London, pp. 1992:1-19.

Maes, D., Van Dael, M., Vanheusden, B., Goovaerts, L., Reumerman, P., Luzardo, N. M., Van Passel, S., 2015. Assessment of the sustainability guidelines of EU Renewable Energy Directive: the case of biorefineries. J Clean Prod, 88, 61-70.

Malerba, F., 2002. Sectoral systems of innovation and production. Res Policy. 31(2): 247-264.

Energ PolicyEnerg PolicyMonfort, E., Garcia-Ten, J., Celades, I., Gomar, S. 2010. Monitoring and possible reduction of HF in stack flue gases from ceramic tiles fired under different conditions. $J$ Fluorine Chem.131, 6-12.

Monfort, E., Mezquita, A., Granel, R., Vaquer, E., Escrig, A., Miralles, A., Zaera, V., 2010. Análisis de consumos energéticos y emisiones de dióxido de carbono en la fabricación de baldosas cerámicas. Bol Soc Esp Ceram V.49 (4) 303-310

Monfort, E., Mezquita, A., Vaquer, E., Ferrer, S., Ros-Dosda, T., 2013. European ceramic industry towards an hypocarbonic economy. Invited conference at 13th Conference and exhibition of the European Ceramic Society. Limoges (Francia), 23-27 June.

Monfort, E.; Mezquita, A.; Vaquer, E.; Mallol, G. Gabaldón-Estevan, D., 2014. La evolución energética del sector español de baldosas cerámicas Bol Soc Esp Ceram V.53 (3) 111-120.

Nassetti G., Ferrari F., Fregni A., Maestri G., 1998. - Assopiastrelle-SNAM -Piastrelle Ceramiche e Energia. Banca dati dei consumi energetici nell'industria delle piastrelle di ceramica. Ed. Centro Ceramico, Bologna.

Nelson, R. (Ed.) 1993. National Innovation Systems. New York, Oxford University Press.

Oikonomou, V., Jepma, C. J. 2008. A framework on interactions of climate and energy policy instruments. Mitig. adapt. strategies glob. chang., 13(2), 131-156.

Pao, H. T., Tsai, C. M., 2010. CO2 emissions, energy consumption and economic growth in BRIC countries. Energ Policy. 38 (12), 7850-7860.

Pao, H. T., Tsai, C. M., 2011a. Multivariate Granger causality between CO2 emissions, energy consumption, FDI (foreign direct investment) and GDP (gross domestic product): evidence from a panel of BRIC (Brazil, Russian Federation, India, and China) countries. Energy, 36(1), 685-693.

Pao, H. T., Tsai, C. M., 2011b. Modeling and forecasting the CO2 emissions, energy consumption, and economic growth in Brazil. Energy. 36(5), 2450-2458.

Rockström, J., Steffen, W., Noone, K., Persson, Å., Chapin, F. S., Lambin, E. F., ... Foley, J. A., 2009. A safe operating space for humanity. Nature, 461(7263), 472-475. 
Rogers, J. C., Simmons, E. A., Convery, I., Weatherall, A., 2008. Public perceptions of opportunities for community-based renewable energy projects. Energ Policy, 36(11), 4217-4226.

Rubik, F., Scholl, G., 2002. Integrated Product Policy (IPP) in Europe-a development model and some impressions. J Clean Prod. 10(5), 507-515.

Smith, A., Raven, R. P. J. M., 2012. What is protective space? Reconsidering niches in transitions to sustainability. Res Policy.41, 1025-1036.

Stock, D. P., 2014. World production and consumption of ceramic tiles. Tile today.85, 54-62.

Streimikiene, D., Šivickas, G. 2008. The EU sustainable energy policy indicators framework. Environ Int. 34(8), 1227-1240.

Tello, P., Weerdmeester, R., 2013. SPIRE roadmap. Sustainable process industry through resource and energy efficiency, Brussels. Available online at http://www.spire2030. eu/uploads/Modules/Publications/spire-roadmap_december_2013_pbp. pdf.

Timellini, G.; Blasco Fuentes, A., 1993. Energy Consumptions and carbon Dioxide Emissions in the Ceramic Tile Sector: Italy and Spain. Ceram. Acta.5(1/2), 41-50.

Vera, I., Langlois, L., 2007. Energy indicators for sustainable development. Energy, 32(6), 875-882.

Weber K. M., Rohracher H., 2012. Legitimizing research, technology and innovation policies for transformative change: Combining insights from innovation systems and multi-level perspective in a comprehensive 'failures' framework. Res Policy. 41(6) 1037-1047.

Westner, G., Madlener, R., 2012. The impact of modified EU ETS allocation principles on the economics of CHP-based district heating systems. J Clean Prod. 20(1), 47-60. 